\title{
Does larval advection explain latitudinal differences in recruitment across upwelling regimes?
}

\author{
Jennifer L. Fisher ${ }^{1, *}$, William T. Peterson ${ }^{2}$, Steven G. Morgan ${ }^{3,4}$ \\ ${ }^{1}$ Cooperative Institute for Marine Resources Studies, Oregon State University, Newport, Oregon 97365, USA \\ ${ }^{2}$ National Oceanographic and Atmospheric Administration — Fisheries, Hatfield Marine Science Center, Newport, \\ Oregon 97365, USA \\ ${ }^{3}$ Bodega Marine Laboratory, University of California Davis, Bodega Bay, California 94923, USA \\ ${ }^{4}$ Department of Environmental Science and Policy, University of California Davis, Davis, California 93510, USA
}

\begin{abstract}
Larval supply determines year-class strength of fisheries and complex ecological interactions among adults of benthic marine species. In upwelling regions, a latitudinal cline in the intensity and persistence of upwelling is thought to affect larval advection and recruitment, thereby regulating the intensity of interactions in adult populations and communities. We tested this hypothesis by determining the monthly cross-shelf abundances of nearshore benthic crustacean larvae throughout development during the peak upwelling season for 7 years in a region of intermittent upwelling and high recruitment $\left(45^{\circ} \mathrm{N}\right)$. We tested whether larvae were found farther offshore during upwelling conditions, and we compared their interspecific cross-shelf distributions to previous results from a region of strong, persistent upwelling $\left(38^{\circ} \mathrm{N}\right)$. We also compared larval abundances across the 2 upwelling regions for 1 year. Most species were retained nearshore, regardless of intra- and inter-annual variations in the intensity of upwelling. In both upwelling regions, larvae of each species consistently occurred at different distances from the shore. Further, there were no differences in nearshore larval abundance across upwelling regions for all but 1 larval stage of 1 species. Thus, latitudinal variations in the intensity and persistence of upwelling do not appear to affect larval survival, providing further evidence that nearshore processes may be a primary determinant of larval delivery to the rocky intertidal across these regions.
\end{abstract}

KEY WORDS: Upwelling · Recruitment limitation · Larval supply · Advection · Larval behavior Resale or republication not permitted without written consent of the publisher

\section{INTRODUCTION}

Benthic populations of sedentary invertebrates are linked through a pelagic larval phase that can last from weeks to months in coastal waters. The larval phase is thought to be the critical link between dispersal and connectivity between populations (Morgan 2001, Underwood \& Keough 2001, Strathmann et al. 2002, Marshall \& Morgan 2011). Larval recruitment, measured as the number of larvae returning to replenish populations, is considered to be a leading determinant of year-class strength of fisheries and complex ecological interactions on rocky shores (Gaines \& Roughgarden 1985, Caley et al. 1996, Shanks \& Roeg- ner 2007). There are well-documented differences in recruitment of invertebrate larvae to rocky coasts along the west coast of the USA (Connolly \& Roughgarden 1998, Connolly et al. 2001, Broitman et al. 2008). Recruitment of rocky intertidal foundation species such as barnacles Balanus spp. and Chthamalus spp. and mussels Mytilus spp. is an order of magnitude greater at northern (Oregon) compared to southern (California) latitudes, resulting in more competition for space (Connolly \& Roughgarden 1998, Connolly et al. 2001). Thus, post-settlement interactions primarily regulate populations and communities in the north, whereas larval recruitment primarily regulates populations and communities in the south. 
A leading hypothesis for this gradient in recruitment is the difference in oceanographic conditions across latitudes. Prevailing equatorward winds during the spring and summer drive the surface waters offshore, lowering sea level at the coast, which initiates the upwelling of cold, nutrient-rich bottom water onto the continental shelf (Huyer 1983). Winds are stronger and more persistent to the south, resulting in stronger offshore advection of surface waters and less recruitment to adult populations and communities (Roughgarden et al. 1988, Menge et al. 2003, 2004). A major assumption of this hypothesis is that offshore advection of upwelled waters overcomes weakly swimming larvae, resulting in low survival of larvae in strong, persistent upwelling regions.

Recent evidence suggests that larvae remain much closer to shore than previously thought in upwelling regions throughout the world, despite large differences in wind forcing. One of the first studies to survey the distribution and abundance of decapod larvae across the shelf reported that larvae were rare beyond $18 \mathrm{~km}$ and that the highest densities were found within $5 \mathrm{~km}$ of the coastline in an intermittent upwelling region off central Oregon (Lough 1974). Later, Shanks \& Shearman (2009) surveyed the larvae of intertidal invertebrates (an echinoid, bivalves, barnacles, ghost shrimp, crabs) along 7 stations ranging from 0.7 to $27 \mathrm{~km}$ from shore off the coast of southern Oregon in 2007. Larvae of all taxa were rare offshore beyond $4.5 \mathrm{~km}$. Similar patterns occurred during 3 years (2000 through 2002) for postlarvae of crabs, and during 2 more years (2005 and 2006) for all larval stages of 45 benthic crustaceans along the windiest coast of the northeast Pacific Ocean with strong persistent upwelling (Morgan et al. 2009a,b, Morgan \& Fisher 2010). Morgan et al. (2009a) found that $92 \%$ of the larvae released by nearshore crustacean species were collected within $6 \mathrm{~km}$ of the shoreline. Further, interspecific vertical and crossshelf larval distributions indicated that larvae of most species in this region reside below the shallow offshore-moving Ekman layer, and as a result, remain nearshore, whereas larvae of other species occurred near the sea surface early in development resulting in transport across the shelf, while later larval stages descended deeper into onshore-flowing upwelling currents to be transported back towards the coast. In the strong upwelling system off Chile, Poulin et al. (2002) found the larvae of an intertidal gastropod remained between the upwelling front and shore, $<8 \mathrm{~km}$ from shore. In the upwelling system off the Iberian Peninsula, pronounced vertical migration timed with the tides assists the export and import of
Carcinus maenus crab larvae between estuaries and the open coast, whereupon vertical migrations with the diel cycle maintains their larvae on the inner shelf (Queiroga \& Blanton 2005, Marta-Almeida et al. 2006, Queiroga et al. 2007, Domingues et al. 2012). In the weak upwelling system off southern California, all larval stages of 2 species of intertidal barnacles Balanus glandula and Chthamalus spp. occurred $1.1 \mathrm{~km}$ from shore, indicating limited cross-shelf transport (Tapia \& Pineda 2007). This growing body of literature supports the cross-shelf distributions initially observed by Lough (1974), indicating that nearshore larval retention is common in upwelling regimes.

The hypothesis of upwelling-induced recruitment limitation gained momentum following a seminal study documenting interannual variations in the seaward limits of barnacle larvae Balanus glandula relative to upwelling intensity (Roughgarden et al. 1988). However, samples were not collected closer than $8 \mathrm{~km}$ from shore, and only the maximum distance larvae occurred from shore was determined, rather than the abundance of larvae far offshore. Because we now know that most larvae occur within kilometers of the coastline throughout development, the results of their study may only apply to a vanishingly small portion of the larval pool. However, the latitudinal gradient in recruitment and adult densities in rocky shore communities was verified in upwelling regimes worldwide (Connolly \& Roughgarden 1998, Connolly et al. 2001, Broitman et al. 2008, Lagos et al. 2008, Pfaff et al. 2011), leaving the processes underpinning these patterns an open question.

It is essential to test hypothetical processes maintaining the latitudinal gradient in larval supply by determining spatial and temporal variations in larval distributions in the plankton relative to ocean conditions, in order to complement previous studies of recruitment onshore. Therefore, we determined abundances of all larval stages of benthic crustaceans across the inner shelf monthly during the peak upwelling season for 7 years in an intermittent upwelling regime $\left(45^{\circ} \mathrm{N}\right)$. We tested whether larvae were found farther offshore during upwelling conditions, and we compared the interspecific cross-shelf distributions to previous studies in the region and a region of strong persistent upwelling $\left(38^{\circ} \mathrm{N}\right)$. We also compared the larval abundances across the 2 contrasting upwelling regions for 1 year. This approach revealed (1) whether larvae were advected farther offshore during strong upwelling conditions, (2) the repeatability of interspecific cross-shelf migrations by larvae in time and space, and (3) the similarity of 
larval abundances across upwelling regions. Together, these data indicated whether larval survival, especially from offshore advection, may be responsible for the latitudinal gradient in recruitment. To be consistent with this hypothesis, larvae in the region of intermittent upwelling and high recruitment should be more abundant and closer to shore than in the region of strong persistent upwelling and recruitment limitation.

\section{MATERIALS AND METHODS}

\section{Study system}

Our study was conducted in the northern and central California Current system (CCS) off Newport, Oregon $\left(44.6^{\circ} \mathrm{N}\right)$ and off Bodega Bay, California $\left(38.3^{\circ} \mathrm{N}\right.$; Fig. 1$)$. The magnitude, persistence and timing of the onset of upwelling-favorable wind forcing vary along the CCS. The northern CCS is characterized by seasonal intermittent upwelling. During summer, equatorward winds create a
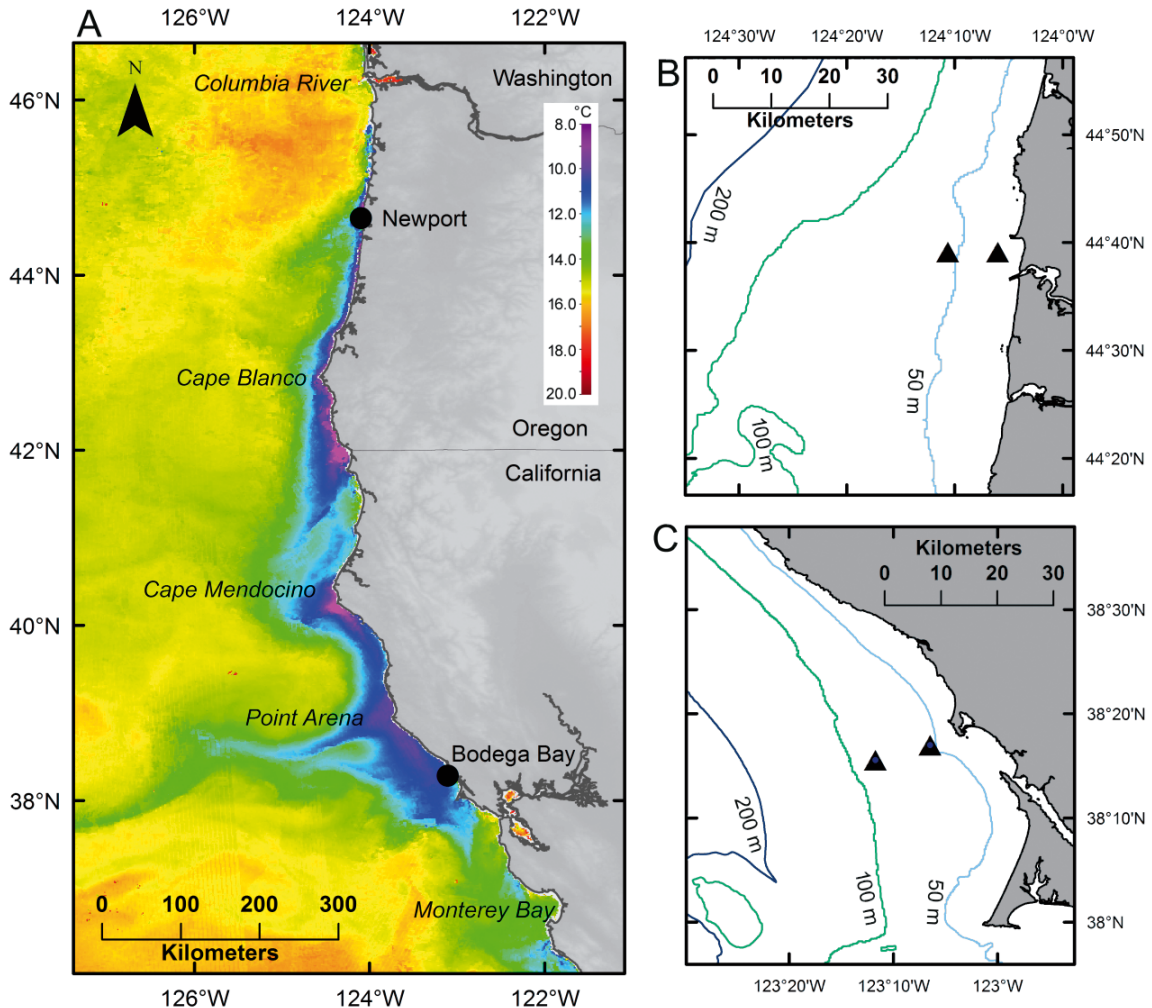

Fig. 1. Study region showing (A) AVHRR satellite image of sea surface temperature from an $8 \mathrm{~d}$ composite (http://coastwatch.pfeg.noaa.gov) centered over the sampling date of 21 June 2006, and station locations (triangles) at the 2 regions; (B) Newport, Oregon, and (C) Bodega Bay, California, USA, in relation to nearshore bathymetry

southward coastal jet in the upper $50 \mathrm{~m}$ of the water column with a deeper poleward undercurrent, especially along the shelf break and slope, that persists despite significant fluctuations in wind stress (Huyer 1983). The cross-shelf location of the coastal jet changes with the strength of wind forcing and has been suggested to be in balance with the upwelling front. It is typically located 15 to $20 \mathrm{~km}$ offshore, becoming progressively displaced farther offshore during upwelling-favorable winds and relaxing back towards shore during periods of weak or no alongshore wind at a frequency of 5 to $12 \mathrm{~d}$ (Huyer 1983, Austin \& Barth 2002). Inshore of the coastal jet, the magnitude of Ekman transport varies, with measured Ekman transport reduced $75 \% 1$ to $2 \mathrm{~km}$ from shore (15 $\mathrm{m}$ water depth), and full Ekman transport occurring 5 to $6 \mathrm{~km}$ from shore in $60 \mathrm{~m}$ of water (Kirincich et al. 2005). On the other hand, the central CCS experiences the strongest most persistent wind forcing and upwelling in the CCS during the spring and summer (Winant et al. 1987, Largier et al. 1993, Dorman et al. 2006). Despite the strong persistent upwelling in this region, coastline topography and shallow depths can also create inshore current reversals and a reduction in Ekman transport and alongshore flow $<10 \mathrm{~km}$ from shore (Lentz \& Chapman 1989, Largier et al. 1993, Kaplan et al. 2005, Roughan et al. 2006). The timing of the onset of upwelling and the total upwelling magnitude also vary across the CCS. Upwelling begins approximately 9 wk earlier, persists for approximately $16 \mathrm{wk}$ longer, and the total magnitude is approximately $78 \%$ greater in the central CCS compared to the northern CCS (Bograd et al. 2009).

\section{Oregon sampling}

Plankton surveys were conducted monthly to twice monthly at 2 stations located 2 and $9 \mathrm{~km}$ from shore in 30 and $60 \mathrm{~m}$ of water, respectively, off Newport, Oregon, for 7 years (Fig. 1). We focused on these 2 nearshore stations because previous larval surveys in this region found that the highest larval concentrations occurred within $5 \mathrm{~km}$ of the coast (Lough 1974). By sampling these 2 stations, we are able to address whether (1) larvae of many species complete larval 
development close to shore, and (2) larval abundance increases $9 \mathrm{~km}$ from shore during upwelling events. We targeted samples collected during the peak upwelling season when most larvae develop (March to June; Lough 1974, Shanks \& Eckert 2005) for 7 years (1998 through 2002, 2009 and 2010). The gap in the time series occurred because the nearshore station was dropped from the sampling plan from 2003 to 2008.

Plankton was collected with a $60 \mathrm{~cm}$ diameter bongo net (335 $\mu \mathrm{m}$ mesh) towed in a double-oblique (down and up) manner over the upper $20 \mathrm{~m}$ of the water column to standardize sampling volumes across sites and because the upper water column is the area of the most active Ekman transport. A flowmeter (General Oceanics model 2030) was mounted inside the mouth of the net to determine the volume of water filtered. All samples were fixed in 10\% buffered formalin. Plankton samples were processed in the laboratory by subsampling with a Folsom plankton splitter, and all crustacean larvae were identified to species and developmental stage with a dissecting microscope. All counts were converted to the total number of individuals per cubic meter of water sampled.

\section{Physical data}

Daily values of the upwelling index (UI) were obtained for our study area $\left(45^{\circ} \mathrm{N} 125^{\circ} \mathrm{W}\right.$; www. pfeg.noaa.gov). The timing (day of year) of the spring transition from winter downwelling to summer upwelling was determined from the cumulative upwelling index (CUI; Bograd et al. 2009). Temperature and salinity of the water column were profiled at each sampling station using a CTD (Seabird Electronics, SBE-19) before each net tow to place plankton concentrations in the context of water column structure.

Some research cruises occurred during the winter downwelling season, prior to the spring transition to summer upwelling conditions, so samples were categorized as occurring before or after the spring transition relative to the cumulative upwelling index (Bograd et al. 2009). Cruises occurring after the spring transition were further classified as occurring during upwelling when temperature at a depth of $50 \mathrm{~m}$ at the station located $9 \mathrm{~km}$ west of Newport was less than $8^{\circ} \mathrm{C}$, and the $5 \mathrm{~d}$ CUI was positive and were classified as occurring during relaxation of upwelling conditions when the opposite conditions were present. The combination of upwelling strength (CUI) $5 \mathrm{~d}$ prior to each sample date and in situ (CTD) temperature and salinity provided a rigorous characterization of the physical conditions during the time of sample collection.

\section{Data analysis}

Crustacean larvae collected off Oregon were identified to species and developmental stage when possible. Pagurids, porcellanids and pinnotherids were not identified to species, because their larvae either are not readily distinguishable without dissection or have not been well described. Larvae of 23 species of pagurids (Lough 1974) and 8 species of pinnotherids (Schmitt 1921) have been reported off the Oregon coast, but few of them have been described. Two species of pinnotherids were likely the predominant larvae collected in this study; Fabia subquadrata and Pinnixa littoralis (Lough 1974). The larvae of porcellanids are difficult to distinguish to species without dissection (Gonor \& Gonor 1973), but they likely consisted of 4 species that are known from the study region (Jensen 1995, Lough 1974).

The total number of larvae collected, mean larval concentration per sampling date and percentage of the total concentration were calculated for each species collected off Oregon. Because of the high density of barnacle larvae, the percentage of total concentration was calculated for barnacles and other taxa separately. Larval stages of all taxa were combined into early, mid, late and postlarvae to simplify presentation. Porcellanids and majids were combined into early and late stages, because they have only 2 larval stages and a postlarval stage. The postlarval stage was only collected for barnacles, pagurids, majids, and cancrids. Additionally, some closely related taxa (Balanus crenatus, B. glandula, B. nubilus, Chthamalus spp., Cancer oregonensis, C. magister, C. productus) were combined for presentation after determining that the relative abundance and spatial distribution of larval stages were similar.

Differences in the larval community between stations and among oceanographic conditions for each sampling date in Oregon were explored using nonmetric multidimensional scaling (NMDS) followed by nonparametric analysis of similarity (ANOSIM). Multivariate analyses were conducted using PRIMER software (version 6.1.10; Plymouth Routines in Multivariate Ecological Research). Data were $\log _{10}(x+1)$ transformed to deemphasize the contribution of very abundant species or larval stages; all analyses were conducted on a Bray-Curtis similarity matrix con- 
structed between samples. A 2-way crossed ANOSIM determined differences in the larval community between stations and among oceanographic conditions. The ANOSIM test statistic (R) is a measure of community separation between factors, with zero indicating no separation and 1 indicating complete separation (Clark \& Warwick 2001). A hierarchical cluster analysis was performed with group average linking and 1000 permutations followed by a similarity profile test (SIMPROF) to designate significantly different clusters $(p=0.01)$.

The relative densities of larval stages at the 2 stations off Oregon indicated whether larvae of each taxon were retained nearshore throughout development or were transported offshore later in development. Analysis of variance (ANOVA) identified interspecific differences in cross-shelf distributions by developmental stage. A 2-way ANOVA was conducted for each taxon to determine whether the distribution of larval stages changed between stations. This test indicated whether larvae were more abundant nearshore throughout development or were found farther offshore later in development (crossshelf distance $\times$ larval stage interaction). To test whether larvae were found farther offshore during different oceanographic conditions, the relative difference in abundance between the 2 sites at each sampling time was used as the response variable in a 1-way ANOVA. If larvae were being swept offshore during upwelling conditions, a significantly greater difference in abundance between the 2 stations during upwelling conditions would be expected. To remove possible differences in larval concentrations across years, the larval abundance for each taxa, larval stage and sample date was standardized by calculating the proportion relative to the total abundance of that taxa across sites within each year. Bartlett's test determined that the data were homoscedastic, so no transformations were applied. Tukey's HSD multiple comparison test assessed differences in the proportions across factors.

\section{California sampling}

We compared larval concentrations that were collected in 2009 from the intermittent upwelling regime off Oregon to those collected in the same year from the strong, persistent upwelling region off Bodega Bay, California (Fig. 1). Two stations off California were sampled at similar depths during the same months as the pair of stations off Oregon. These stations were located 1 and $4 \mathrm{~km}$ from shore in 28 and $80 \mathrm{~m}$ of water and were sampled 3 times (28 May, 25 June and 15 July) in 2009. Larvae were sampled using an electronically tripped Tucker trawl with a mouth opening of $0.5 \mathrm{~m}^{2}$ fitted with $335 \mu \mathrm{m}$ mesh nets. Samples were collected at 3 discrete depths spanning the water column but were integrated for comparison to the samples from Oregon. Capture efficiency of crustacean zooplankton by the sampling devices (bongo net vs. tucker trawl) deployed in the 2 regions is similar, so a net correction factor was not applied (Pepin \& Shears 1996).

To test for ontogenetic differences in cross-shelf patterns and larval abundance between upwelling regions, we conducted a 3-way ANOVA for each taxon. Upwelling region by cross-shelf distance interactions indicated whether larvae were swept farther offshore in the stronger upwelling region of California. Larval densities were transformed $\log _{10}(x+1)$ to meet assumptions of homogeneity of variances and normality. Tukey's HSD multiple comparisons detected significant differences in larval densities across factors. Nonsignificant higher order ( $\geq 2$-way) interactions were not reported for simplicity.

\section{Retrospective cross-shelf distributions}

To determine the repeatability of interspecific cross-shelf distributions, we compared the maximum larval density (no. larvae $100 \mathrm{~m}^{-3}$ ) of 14 taxa collected at each station from this study to those collected in the same region across the shelf and in oceanic waters from 1969 to 1971 (Lough 1974), and from samples collected across the shelf in the persistent upwelling region off Bodega Bay, California, in 2005 and 2006 (Morgan et al. 2009a).

\section{RESULTS}

\section{Oceanographic conditions during cruises}

Upwelling intensity, measured by the average monthly anomaly of the UI during the sampling months (March through June), varied slightly across years (Fig. 2A). Surprisingly, the strongest upwelling occurred during 1998, which was characterized by strong El Niño conditions (Peterson et al. 2002). Upwelling was weakest in 2010 during a moderate El Niño, with the other years being moderately strong $(2001,2002,2009)$ or moderately weak $(1999,2000)$. In 2000 and 2001, the onset of upwelling was delayed 2 to 3 wk compared to the long-term mean (day of the 

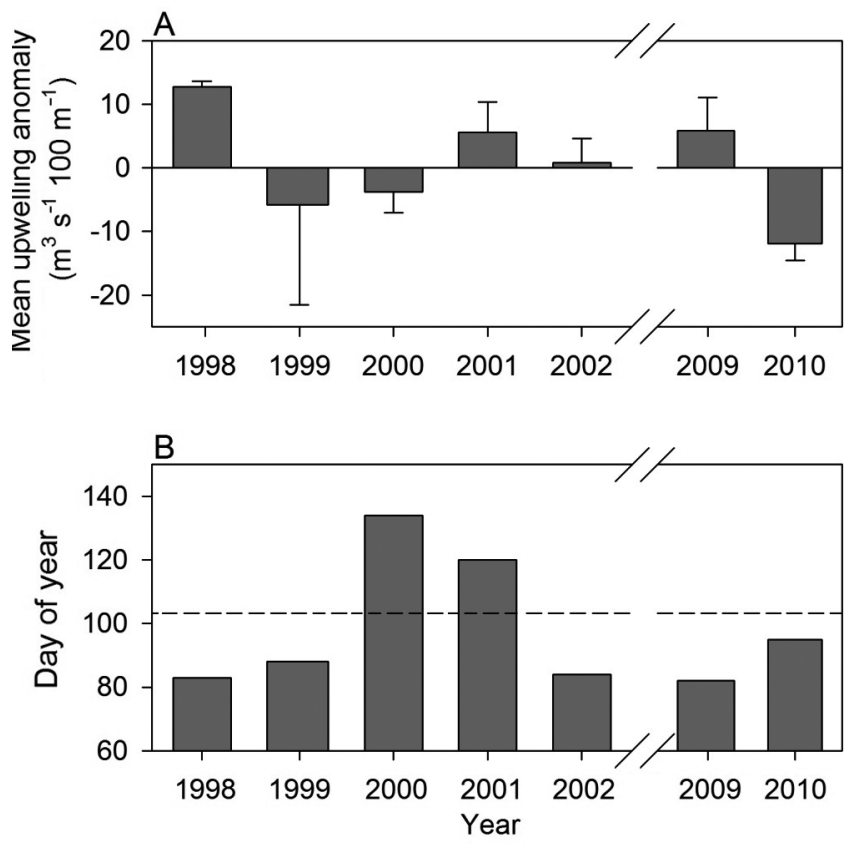

Fig. 2. Interannual differences in the magnitude and timing of upwelling off Newport, Oregon, characterized by (A) the monthly anomaly of the Bakun upwelling index, averaged (+1 SE) across the sampling period (March through June) each year. Positive values indicate stronger than average upwelling; negative values indicate weaker upwelling or downwelling conditions. (B) Timing of the spring transition measured from the cumulative Bakun upwelling index. Dashed line $=$ mean day of spring transition (day of the year 103.3) from 1969 to 2012. Sampling did not occur during 2003 through 2008

year 103.3 from 1969 to 2012) while the onset of upwelling occurred approximately 2 wk earlier than the long-term mean during the other years (Fig. 2B).

Deep-water $(50 \mathrm{~m})$ temperature and salinity during the 26 sampling dates ranged from $7.0^{\circ} \mathrm{C}$ and a salinity of 34 during upwelling, to $11.8^{\circ} \mathrm{C}$ during the El Niño of 1998 and a salinity of 32.5 during a relaxation event in 2009 (Fig. 3). Four cruises were conducted before the physical spring transition in March and 2 in April during 2000 and 2001 when upwelling was delayed (Figs. 2B \& 3). Eight cruises were conducted during relaxation conditions during April, May and June, with 1 cruise occurring during relaxation conditions in March of 2009 when the transition to upwelling conditions occurred early (Figs. 2B \& 3). Twelve cruises were conducted during upwelling conditions during April, May and June across all years with the exception of the El Niño of 1998, when upwelling conditions (as defined hydrographically) were not observed. Upwelling conditions were most consistently observed during cruises conducted in June.

\section{Species abundance}

Six species of barnacles were the most numerous, comprising $96 \%$ of all larvae of benthic crustaceans collected (Table 1). Three barnacle species, Balanus crenatus, B. glandula, and Chthamalus dalli, comprised $99.9 \%$ of the 6 barnacle species collected during the study. Larvae of 14 taxa of crabs and shrimp were collected from 9 different families (Table 1). Ten taxa (Neotrypaea californiensis, Paguridae, Porcellanidae, Pinnotheridae, Pugettia spp., Hemigrapsus spp., Lophopanopeus bellus, Cancer oregonensis, Cancer magister) represented $90 \%$ of all crab larvae collected and were used for statistical analyses (Table 1).

\section{Larval assemblage across sites and oceanographic conditions}

The larval assemblage across the 52 samples collected at the 2 stations in Oregon, as indexed by NMDS, were mainly separated by cross-shelf distance (ANOSIM, distance, $\mathrm{R}=0.28, \mathrm{p}=0.01$; Fig. 4A) as opposed to oceanographic condition (ANOSIM,

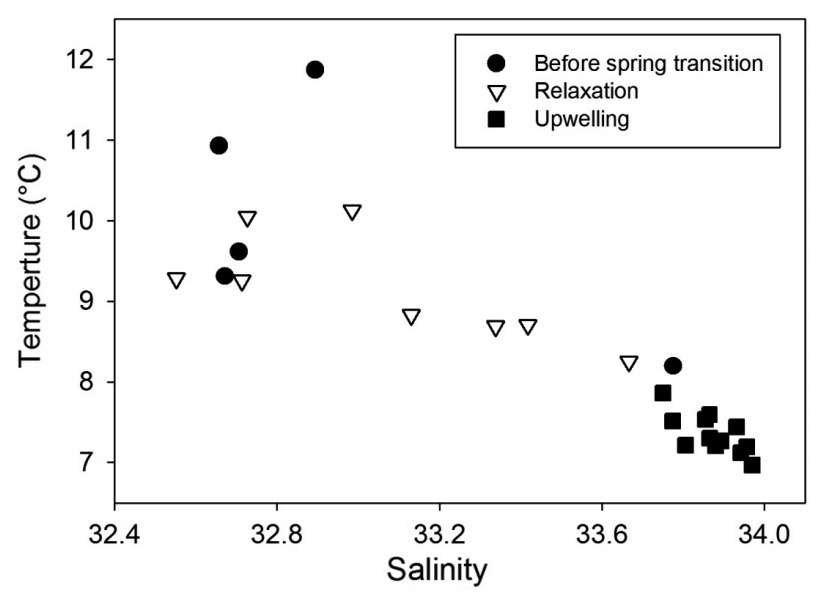

Fig. 3. Temperature and salinity at $50 \mathrm{~m}$ water depth during 26 sampling dates $9 \mathrm{~km}$ offshore from Newport, Oregon. Dates were categorized based on whether they occurred before the spring transition or after the onset of the upwelling season during relaxation or upwelling conditions. Samples were considered to be collected prior to the spring transition from the winter downwelling season to the summer upwelling period, as measured from the cumulative upwelling index. Samples were considered to be collected during relaxation conditions when the deep water $(50 \mathrm{~m})$ temperature at the station was $>8^{\circ} \mathrm{C}$ and when equatorward winds were weak or poleward (downwelling); upwelling conditions occurred when conditions were opposite. Data were not available for 1 cruise conducted before the spring transition in March 2002 
Table 1. Twenty taxa of crustacean larvae collected within $9 \mathrm{~km}$ of shore off Newport, Oregon, from March through June over 7 years (1998 to 2002, 2009 and 2010). The number of larval stages, number of larval stages collected, total number of larvae collected, number collected per sampling date $(\mathrm{n}=26)$, and percentage of all larvae collected are reported. The percentage of all Cirripedia larvae collected was calculated separately from other taxa because of their greater concentrations

\begin{tabular}{|c|c|c|c|c|c|c|}
\hline Family & Taxon & $\begin{array}{c}\text { No. larval } \\
\text { stages }\end{array}$ & $\begin{array}{c}\text { No. stages } \\
\text { collected }\end{array}$ & Total $\left(\mathrm{m}^{-3}\right)$ & $\begin{array}{l}\text { Mean trip } \\
\quad( \pm \text { SD })\end{array}$ & Total $(\%)$ \\
\hline \multirow[t]{7}{*}{ Cirripedia } & Balanus crenatus $^{\mathrm{a}}$ & 6 & 6 & 56465.6 & $2091.3 \pm 1920.8$ & 84.4 \\
\hline & Balanus glandula ${ }^{\mathrm{a}}$ & 6 & 6 & 6753.8 & $250.1 \pm 180.4$ & 10.1 \\
\hline & Chthalamus dalli ${ }^{\mathrm{a}}$ & 6 & 6 & 3624.7 & $134.2 \pm 130.3$ & 5.4 \\
\hline & Balanus nubilus ${ }^{\mathrm{a}}$ & 6 & 6 & 77.7 & $2.9 \pm 1.6$ & 0.1 \\
\hline & Semibalanus cariosus ${ }^{\mathrm{b}}$ & 6 & 1 & 7.1 & $0.3 \pm 0.2$ & 0.01 \\
\hline & Solidobalanus hesperius ${ }^{\mathrm{b}}$ & 6 & 4 & 1.3 & $0.05 \pm 0.05$ & 0.002 \\
\hline & & & & & & $\overline{100.0}$ \\
\hline \multirow[t]{2}{*}{ Thalassinidea } & Neotrypaea californiensis & 6 & 5 & 513.3 & $19.0 \pm 6.9$ & 19.1 \\
\hline & Upogebia pugettensis $^{\mathrm{b}}$ & 4 & 3 & 25.8 & $1.0 \pm 0.3$ & 1.0 \\
\hline Hippidae & Emerita analoga ${ }^{\mathrm{b}}$ & 6 & 3 & 0.5 & $0.02 \pm 0.01$ & 0.02 \\
\hline Paguroidea & Paguridae & 5 & 5 & 226.2 & $8.3 \pm 3.7$ & 8.4 \\
\hline Porcellanidae & Porcellanidae & 3 & 2 & 771.9 & $28.5 \pm 13.0$ & 28.7 \\
\hline Pinnotheridae & Pinnotheridae & 6 & 5 & 626.4 & $23.8 \pm 7.3$ & 23.3 \\
\hline \multirow[t]{2}{*}{ Majidae } & Pugettia spp. & 3 & 3 & 26.3 & $1.0 \pm 0.3$ & 1.0 \\
\hline & Chionoecetes bairdi ${ }^{\text {b }}$ & 3 & 1 & 0.3 & $0.01 \pm 0.01$ & 0.01 \\
\hline \multirow[t]{2}{*}{ Grapsidae } & Hemigrapsus spp. & 6 & 5 & 22.4 & $0.8 \pm 0.2$ & 0.8 \\
\hline & Pachygrapsus crassipes ${ }^{\mathrm{b}}$ & 6 & 1 & 0.8 & $0.03 \pm 0.02$ & 0.03 \\
\hline \multirow[t]{3}{*}{ Cancridae } & Cancer oregonensis $^{\mathrm{a}}$ & 6 & 6 & 443.0 & $16.4 \pm 6.3$ & 16.5 \\
\hline & Cancer magister ${ }^{\mathrm{a}}$ & 6 & 5 & 12.3 & $0.5 \pm 0.2$ & 0.5 \\
\hline & Cancer productus ${ }^{\mathrm{a}}$ & 6 & 4 & 0.8 & $0.03 \pm 0.01$ & 0.03 \\
\hline \multirow[t]{2}{*}{ Xanthidae } & Lophopanopeus bellus & 5 & 3 & 15.7 & $0.6 \pm 0.2$ & 0.6 \\
\hline & & & & & & $\overline{100.0}$ \\
\hline
\end{tabular}
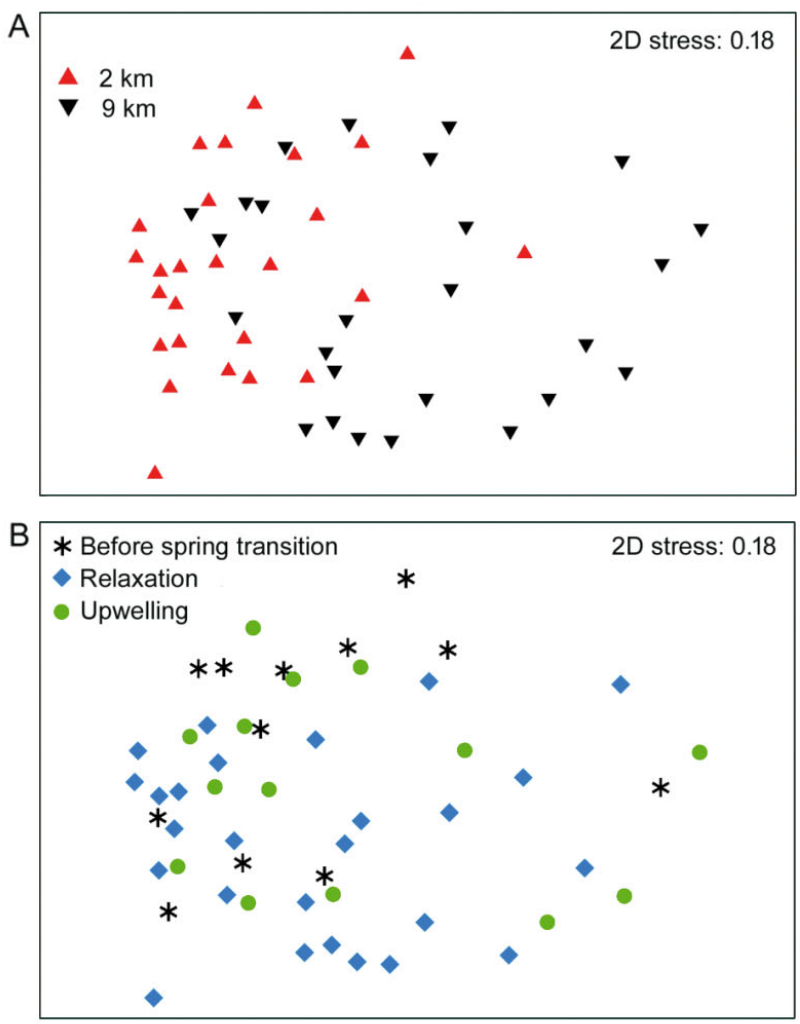

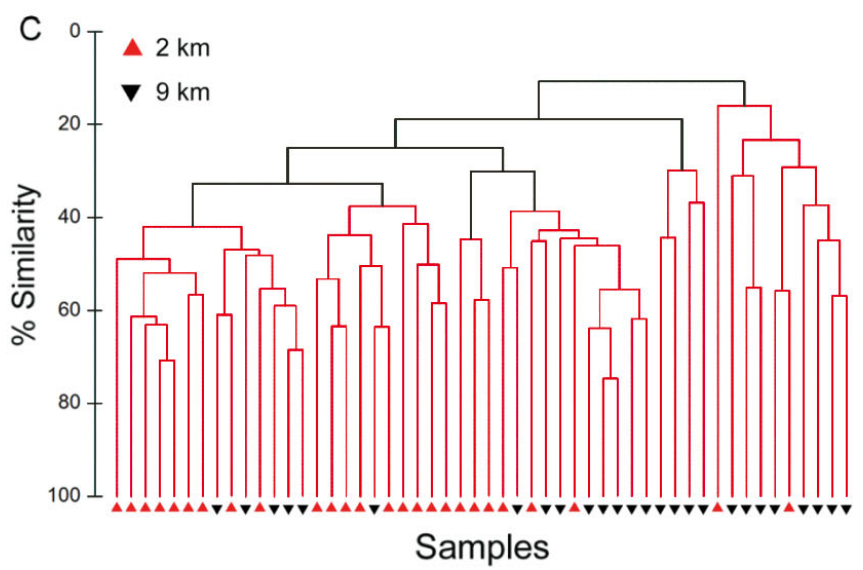

Fig. 4. Larval assemblage patterns from 52 samples collected at 2 stations, 2 and $9 \mathrm{~km}$ from shore off Newport, Oregon over 7 years (1998 to 2001, 2009 and 2010). Larval assemblage patterns from nonmetric multidimensional scaling show (A) the cross-shelf distance of the station, (B) the oceanographic condition (before the spring transition, relaxation or upwelling) and (C) cluster analysis. Solid black lines on the cluster analysis indicate significantly different clusters from a SIMPROF test $(p=0.01)$ 
Fig. 5. Mean proportion within each year $\left(\mathrm{m}^{-3}\right.$ $+1 \mathrm{SE}$ ) of 3 taxa of crustaceans that developed within $2 \mathrm{~km}$ from shore regardless of oceanographic conditions (before the spring transition, upwelling, relaxation) off Newport, Oregon, from March to June over 7 years (1998 to 2002, 2009 and 2010). Species with similar patterns were combined, and larval stages were classified as early, mid, late and postlarvae (PL) to simplify presentation. Porcellanids only have 2 larval stages (early and late) and a PL stage

ocean phase, $\mathrm{R}=0.05, \mathrm{p}=0.17$; Fig. $4 \mathrm{~B}$ ). Cluster analysis revealed 2 main clusters with a $15 \%$ similarity that mainly corresponded to cross-shelf distance (Fig. 4C). One cluster represented 10 samples, only 2 of which were from the inshore station, and those samples were collected during the El Niño and La Niña of 1998 and 1999 when the physical characteristics and the copepods in our samples were previously considered to be homogenous across the

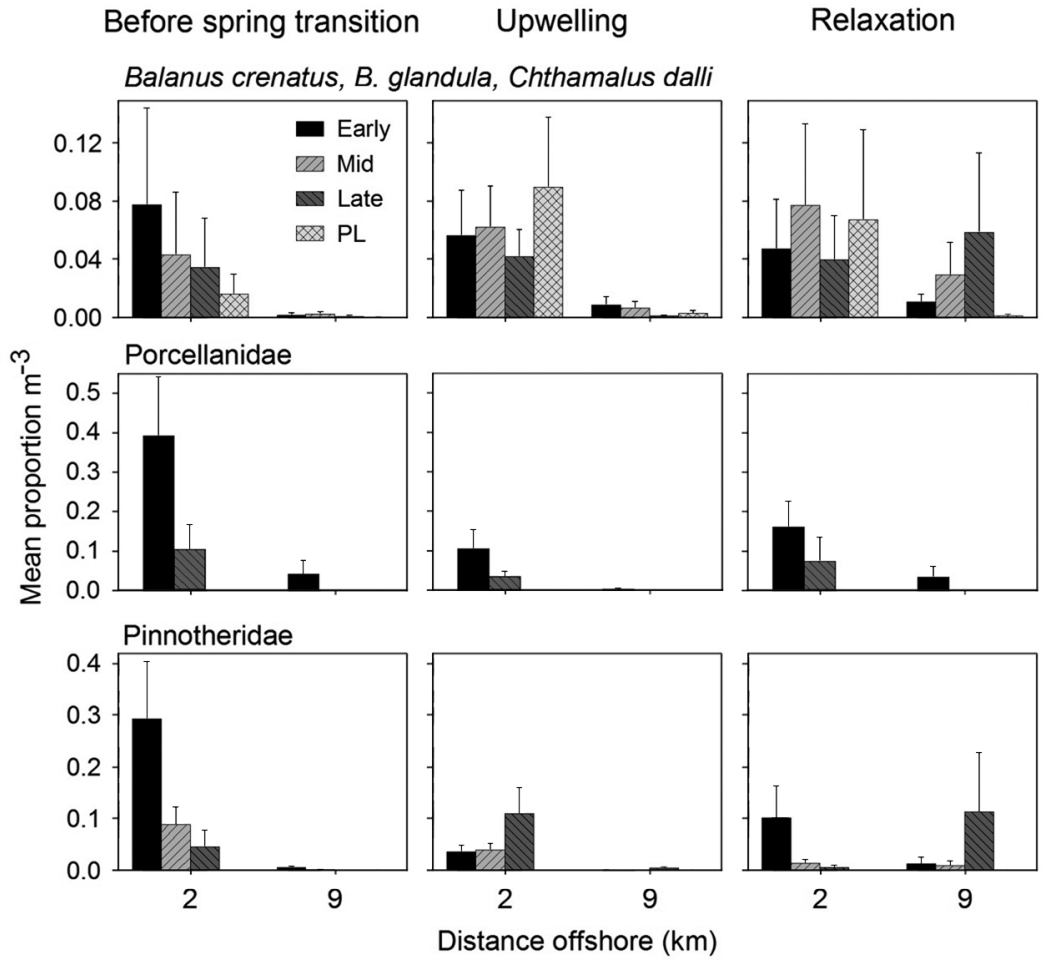

Before spring transition

Upwelling
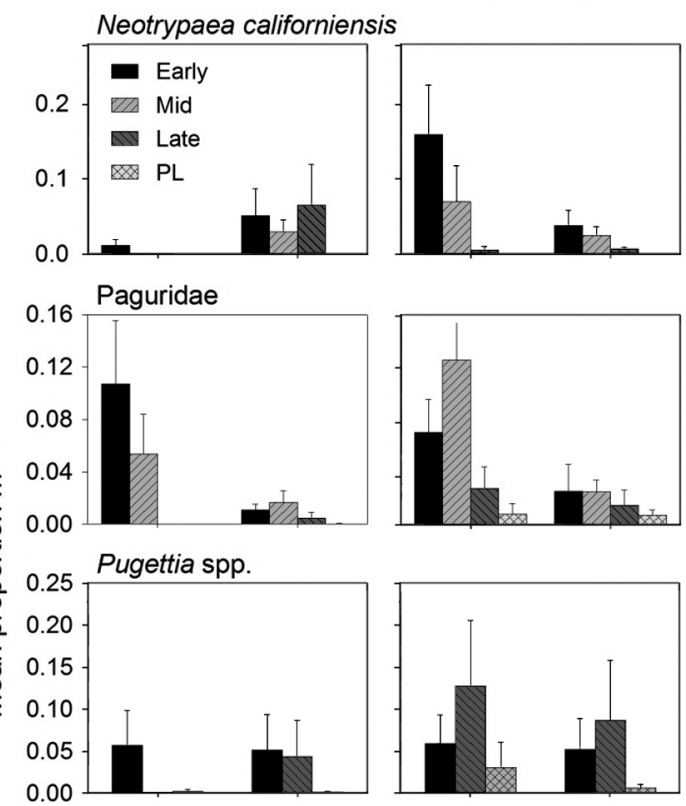

Relaxation
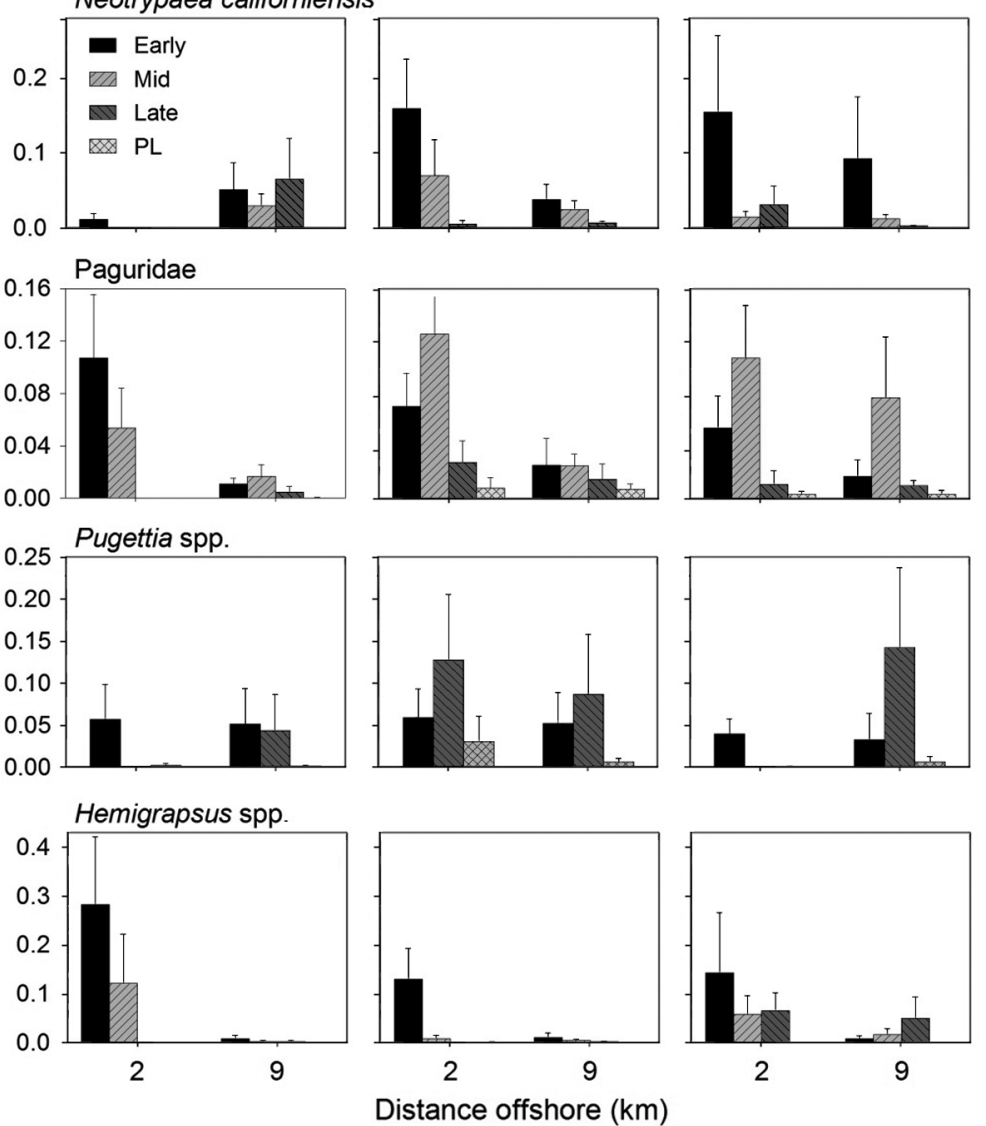

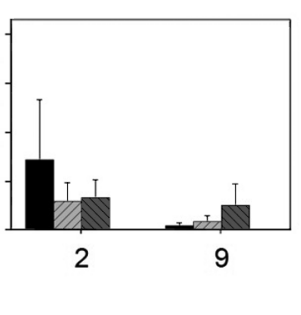

entire shelf (Peterson et al. 2002). The other cluster representing the majority (42) of the samples can be broken down further at the $28 \%$ similarity into 3 more clusters: 1 from samples collected at the inshore station and 2 from samples collected at both stations.

\section{Larval advection between stations and among oceanographic conditions}

The relative abundance of larval stages for each taxon at the 2 stations indicated whether larvae occurred mostly within 2 $\mathrm{km}$ from shore, within $9 \mathrm{~km}$ from shore, or likely migrated across the shelf, beyond our study region. All larval stages of 3 taxa (barnacles, pinnotherids, porcellanids) were almost solely collected

Fig. 6. Mean proportion within each year $\left(\mathrm{m}^{-3}\right.$ $+1 \mathrm{SE}$ ) of 4 taxa of crustaceans that developed within $9 \mathrm{~km}$ from shore regardless of oceanographic conditions (before the spring transition, upwelling, relaxation) off Newport, Oregon from March to June over 7 years (1998 to 2002, 2009 and 2010). Larval stages were classified as early, mid, late and postlarvae (PL) to simplify presentation. Majids only have 2 larval stages (early and late) and a PL stage 
at the inshore station (Fig. 5, Table 2), indicating that they completed development within $2 \mathrm{~km}$ from shore. There were no differences in the abundance of larval stages for the barnacles or pinnotherids, but early-stage porcellanids were collected in higher numbers compared to their late-stage larvae (Table 2). The relative difference in larval abundance between the 2 stations did not vary across oceanographic conditions for the barnacles and porcellanids; however, early stage pinnotherid larvae were more abundant at the inshore station before the spring transition, possibly indicating an earlier larval release compared to the other taxa (Fig. 5, Table 2).

All larval stages of 4 other taxa, Neotrypaea californiensis, pagurids, Pugettia spp., and Hemigrapsus spp. were collected at both stations (Fig. 6, Table 2). The early-stage larvae of Hemigrapsus spp. and the early and mid-stage larvae of the pagurids were more abundant at the inshore station, indicating nearshore larval release and retention for these taxa (Table 2). The relative difference in larval abundance between the 2 stations did not vary for these taxa, indicating that ocean condition does not affect the cross-shelf distribution for $N$. californiensis, pagurids, Pugettia spp., and Hemigrapsus spp. (Fig. 6, Table 2).

Early stage larvae of the remaining 2 taxa, Cancer spp. and Lophopanopeus bellus, occurred mainly at the inshore station, whereas early and mid-stage larvae were collected at the offshore station. Late stages were not collected, with the exception of Cancer spp. postlarvae, which were collected during relaxation conditions at the outer station (Fig. 7). Early stage larvae of the cancrids were more abundant at the inshore station, indicating that they were released nearshore (Table 2). Hence, it appeared that larvae of these 2 taxa were released nearshore, migrated onto the mid shelf as early and mid-stage larvae, and then likely migrated into the open ocean beyond our study area as late stage larvae. The postlarvae of at least the cancrids returned to the shelf to settle (Fig. 7). The relative difference in larval abundance between the 2 stations did not vary for these taxa, indicating that ocean conditions do not affect cross-shelf migrations of Cancer spp. and L. bellus (Fig. 7, Table 2).

\section{Larval abundance between upwelling regions}

Eight taxa were collected at both the intermittent upwelling region off central Oregon $\left(45^{\circ} \mathrm{N}\right)$ and the persistent upwelling region off northern California $\left(38^{\circ} \mathrm{N}\right)$. Of these 8 taxa, only postlarvae of Balanus nubilus were more abundant off California than Oregon (Fig. 8, Table 3). Despite large differences in upwelling strength and persistence, and onshore settlement between these regions, there were no significant differences in larval abundance of the other 7 taxa collected between these regions (Fig. 8, Table 3). All larval stages of 4 of the 8 taxa (Balanus crenatus, pagurids, porcellanids, pinnotherids) were more abundant at the inshore station in both regions (Fig. 8, Table 3), indicating that nearshore larval retention is a pattern common to both study regions.

\section{DISCUSSION}

\section{Cross-shelf larval advection}

We have provided the longest time-series of crossshelf larval abundance data published to date for an upwelling regime. Strong patterns of nearshore larval retention were apparent despite variability in the magnitude and timing of the onset of upwelling across 7 years. Five of the 9 taxa collected were more

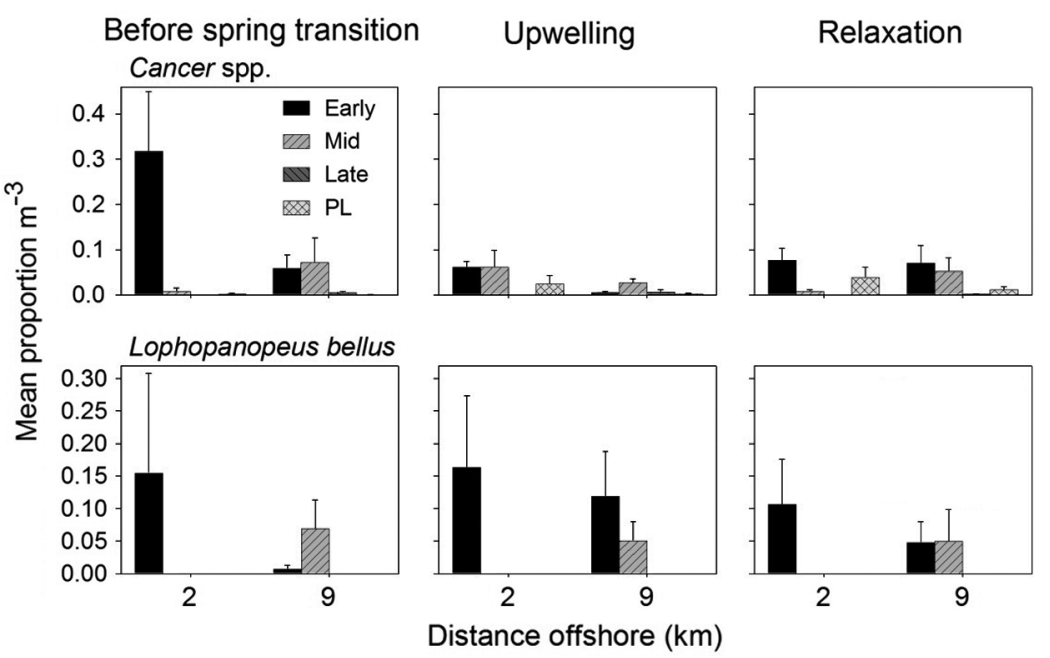

Fig. 7. Mean proportion within each year $\left(\mathrm{m}^{-3}+1 \mathrm{SE}\right)$ of 2 taxa of crustaceans that likely developed offshore of our sampling stations (>9 $\mathrm{km}$ from shore) regardless of oceanographic conditions (before the spring transition, upwelling, relaxation) off Newport, Oregon, from March to June over 7 years (1998 to 2002, 2009 and 2010). Species with similar patterns were combined, and larval stages were classified as early, mid, late and postlarvae (PL) to simplify presentation 
abundant at the inshore station, while all of the larval stages of 3 of these taxa were almost solely found at the inshore station-indicating that they completed development within $2 \mathrm{~km}$ of the coastline. Larvae were not found farther offshore during upwelling conditions. These patterns of nearshore larval retention across taxa and changing oceanographic conditions are consistent with an earlier study in this region (Lough 1974) and with studies from the weak upwelling region off southern California (Tapia \& Pineda 2007), the intermittent upwelling regions off the Iberian Peninsula and southern Oregon (Queiroga et al. 2007, Shanks \& Shearman 2009), and from the strong persistent upwelling regions off northern California and Chile (Poulin et al. 2002, Morgan et al. 2009a, 2012, Morgan \& Fisher 2010).

Although the cross-shelf extent of our study was limited to $9 \mathrm{~km}$ from shore, the interspecific crossshelf distributions of larvae were comparable to those from samples collected along the same hydrographic transect to $111 \mathrm{~km}$ offshore during 1969 to 1971 (Lough 1974; our Fig. 9). Lough (1974) observed the highest concentrations of all larvae within $5 \mathrm{~km}$ of shore, and larvae of all but a few nearshore species were never collected beyond $18 \mathrm{~km}$. Only the later larval stages of Cancer magister, C. oregonensis and Lophopanopeus bellus commonly occurred far offshore, indicating that these species migrated across the shelf - which was also apparent during our study. Larvae of Pugettia spp. also occurred beyond $18 \mathrm{~km}$ during the earlier study, but they were orders of magnitude more abundant within $2 \mathrm{~km}$ of the coast (Lough 1974), which is consistent with our findings during 7 years of sampling. Thus the results from our study, which was concentrated on the inner shelf over a longer time period, were comparable to earlier work that sampled across the continental shelf and into oceanic waters.

Interspecific cross-shelf distributions of larvae off central Oregon also were similar to other regions of the CCS: southern Oregon (Shanks \& Shearman 2009) and northern California (Morgan et al. 2009a,b; our Fig. 9). The highest larval abundances of all taxa occurred nearshore $(<6 \mathrm{~km})$, and many species (i.e. Balanus crenatus, B. glandula, Chthamalus dalli, pinnotherids, porcellanids) completed larval development there. Larvae of Neotrypaea californiensis and 3 species of Pagurus also completed development nearshore $(<6 \mathrm{~km})$ off southern Oregon and northern California, but they were moderately abundant far-

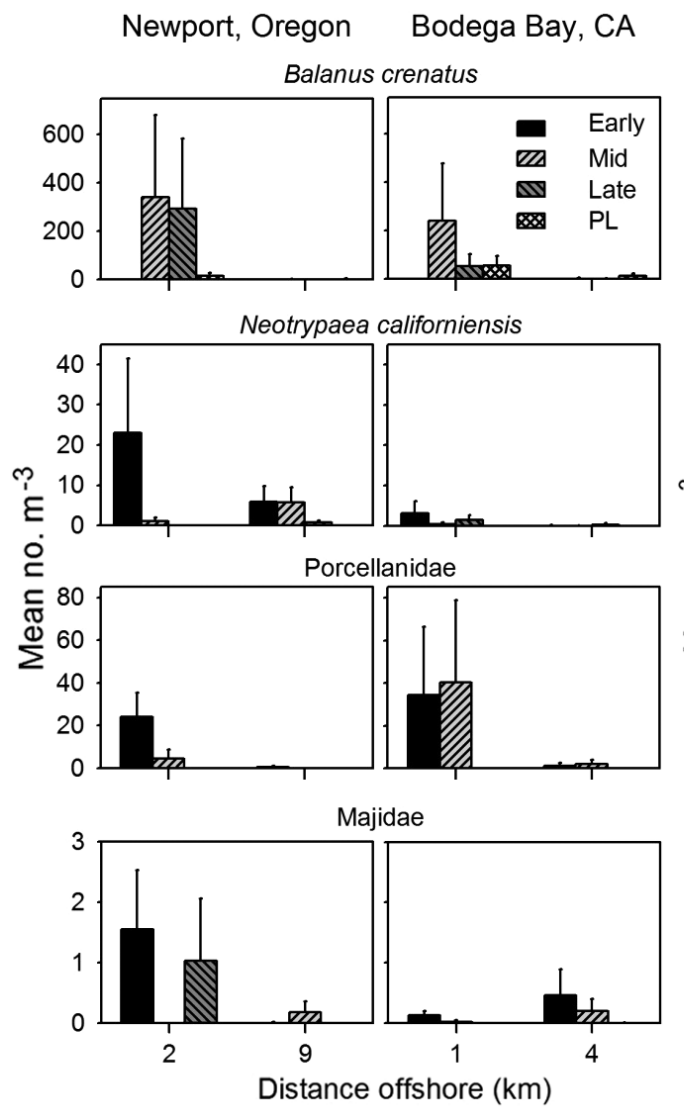

Fig. 8. Cross-shelf distributions of 8 taxa of crustaceans collected at 2 stations in similar water depths off Newport, Oregon, and Bodega Bay, California, in 2009. Mean larval concentration $\left(\mathrm{m}^{-3}+1 \mathrm{SE}\right)$ relative to cross-shelf distance and upwelling region. Species with similar patterns were combined, and larval stages were classified as early, mid, late and postlarvae (PL) to simplify presentation. Key shown for Balanus crenatus applies to all panels except Pinnotheridae 


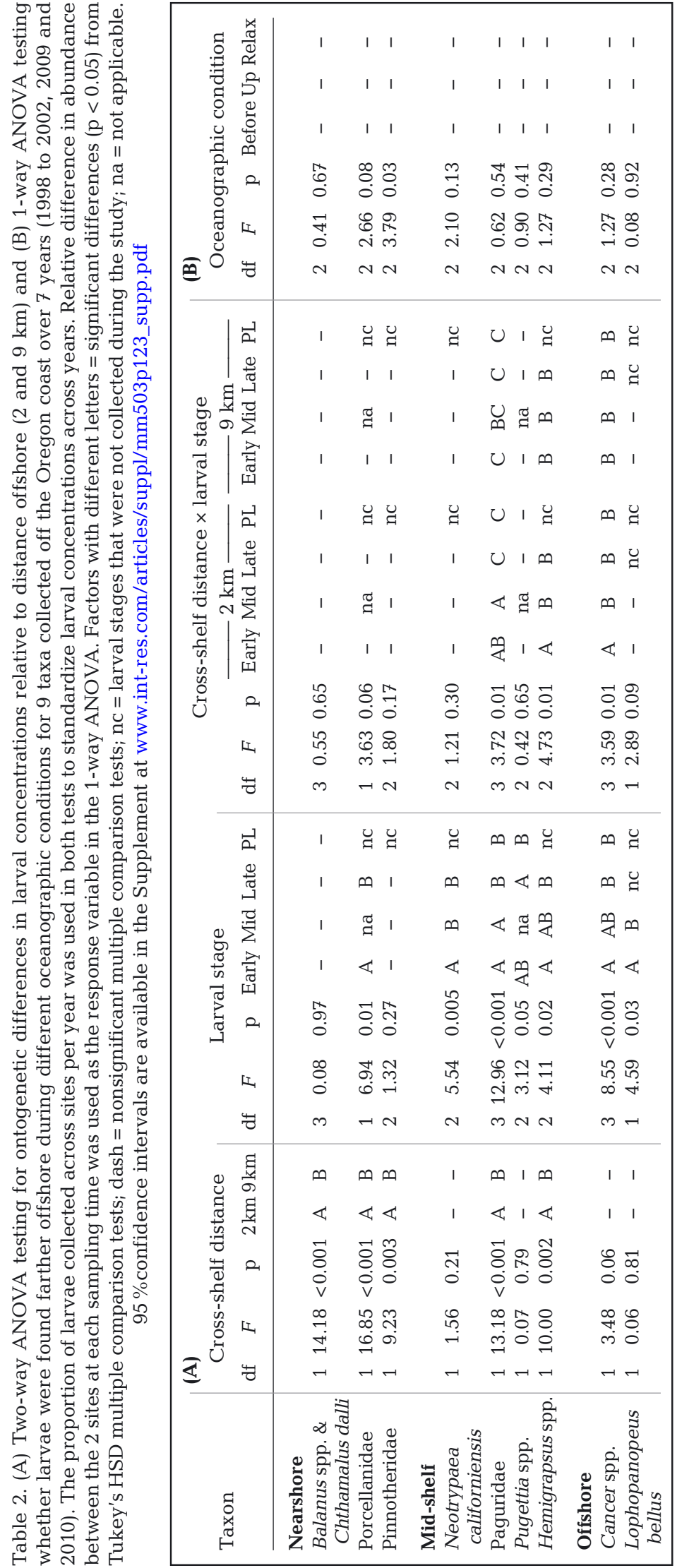

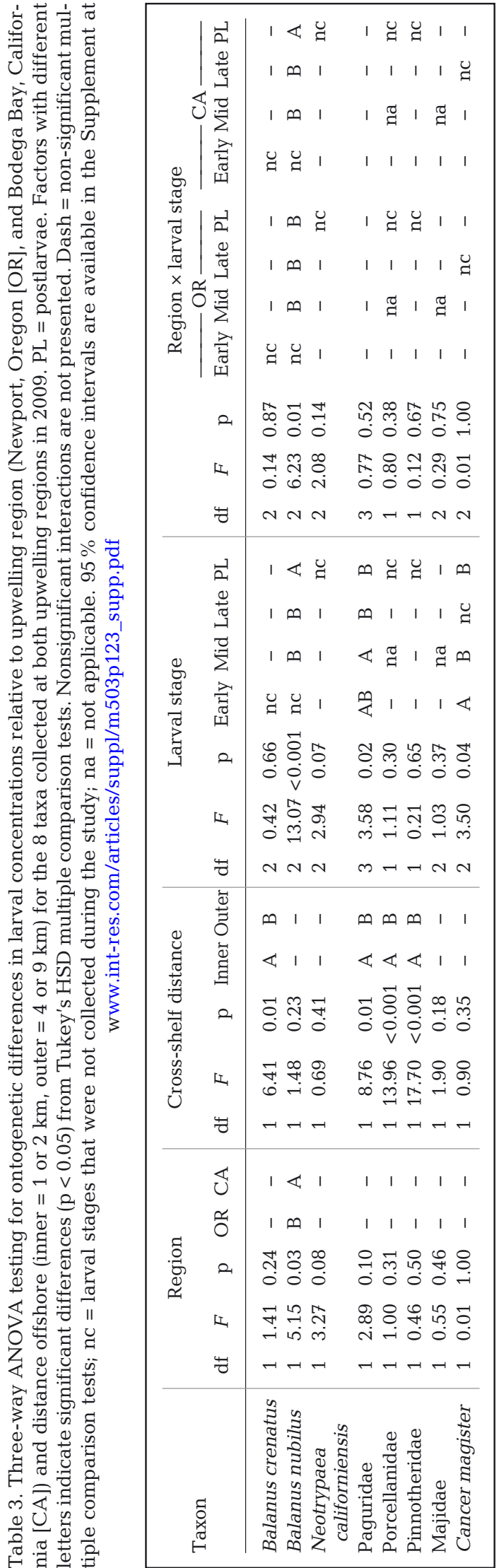




\begin{tabular}{|c|c|c|c|c|c|c|c|c|c|c|c|c|c|}
\hline \multicolumn{2}{|c|}{$\begin{array}{l}\text { Distance from the } \\
\text { exposed shoreline }(\mathrm{km})\end{array}$} & $1-2$ & $4-5$ & $9-11$ & $18-20$ & 28 & 37 & 46 & 55 & 65 & 75 & 90 & 110 \\
\hline \multirow{2}{*}{ Balanus crenatus } & $\mathrm{OR}^{\mathrm{b}}$ & & -- & & -- & $\begin{array}{ll}- \\
-\end{array}$ & -- & -- & -- & -- & -- & -- & -- \\
\hline & $\mathrm{CA}$ & & & & & & -- & -- & -- & -- & -- & -- & -- \\
\hline \multirow{2}{*}{ Balanus glandula } & $\mathrm{OR}^{\mathrm{b}}$ & & -- & & -- & -- & -- & -- & -- & -- & -- & -- & -- \\
\hline & $\mathrm{CA}$ & & & & & & -- & -- & -- & -- & -- & -- & -- \\
\hline \multirow{2}{*}{ Balanus nubilus } & $\mathrm{OR}^{\mathrm{b}}$ & & -- & & -- & -- & -- & -- & -- & -- & -- & -- & -- \\
\hline & $\mathrm{CA}$ & & & & & & -- & -- & -- & -- & -- & -- & -- \\
\hline \multirow{2}{*}{ Chthamalus spp. } & $\mathrm{OR}^{\mathrm{b}}$ & & -- & & -- & -- & -- & -- & -- & -- & -- & -- & -- \\
\hline & $\mathrm{CA}$ & & & & & & -- & -- & -- & -- & -- & -- & -- \\
\hline \multirow{2}{*}{$\begin{array}{l}\text { Neotrypaea } \\
\text { californiensis }\end{array}$} & $\mathrm{OR}^{\mathrm{b}}$ & & -- & & -- & -- & -- & -- & -- & -- & -- & -- & -- \\
\hline & $\mathrm{CA}$ & & & & & & -- & -- & -- & -- & -- & -- & -- \\
\hline \multirow{3}{*}{ Paguridae } & $\mathrm{OR}^{\mathrm{a}}$ & & & & & & & & & & & & \\
\hline & $O R^{b}$ & & -- & & -- & -- & -- & -- & -- & -- & -- & -- & -- \\
\hline & $\mathrm{CA}$ & & - & & & & -- & -- & -- & -- & -- & -- & -- \\
\hline \multirow{3}{*}{ Porcellanidae } & $\mathrm{OR}^{\mathrm{a}}$ & & & & & & & & & & & & \\
\hline & $O R^{b}$ & & -- & & -- & -- & -- & -- & -- & -- & -- & -- & -- \\
\hline & $\mathrm{CA}$ & & & & & & -- & -- & -- & -- & -- & -- & -- \\
\hline \multirow{3}{*}{ Pinnotheridae } & $\mathrm{OR}^{\mathrm{a}}$ & & & & & & & & & & & & \\
\hline & $O R^{b}$ & & -- & & -- & -- & -- & -- & -- & -- & -- & -- & -- \\
\hline & $\mathrm{CA}$ & & & & & & -- & -- & -- & -- & -- & -- & -- \\
\hline \multirow{3}{*}{ Majidae } & $\mathrm{OR}^{\mathrm{a}}$ & & & & & & & & & & & & \\
\hline & $O R^{b}$ & & -- & & -- & -- & -- & -- & -- & -- & -- & -- & -- \\
\hline & $\mathrm{CA}$ & & & & & & -- & -- & -- & -- & -- & -- & -- \\
\hline \multirow{3}{*}{ Hemigrapsus spp. } & $\mathrm{OR}^{\mathrm{a}}$ & & & & & & & & & & & & \\
\hline & $O R^{b}$ & & -- & & -- & -- & -- & -- & -- & -- & -- & -- & -- \\
\hline & $\mathrm{CA}$ & & & & & & -- & -- & -- & -- & -- & -- & -- \\
\hline \multirow{2}{*}{$\begin{array}{l}\text { Cancer } \\
\text { antennarius }\end{array}$} & $\mathrm{OR}^{\mathrm{b}}$ & & -- & & -- & -- & -- & -- & -- & -- & -- & -- & -- \\
\hline & $\mathrm{CA}$ & & & & & 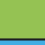 & -- & -- & -- & -- & -- & -- & -- \\
\hline \multirow{3}{*}{ Cancer magister } & $\mathrm{OR}^{a}$ & & & & & & & & & & & & \\
\hline & $O R^{b}$ & & -- & & -- & -- & -- & -- & -- & -- & -- & -- & -- \\
\hline & $\mathrm{CA}$ & & & & & & -- & -- & -- & -- & -- & -- & -- \\
\hline \multirow{2}{*}{$\begin{array}{l}\text { Cancer } \\
\text { oregonensis }\end{array}$} & $\mathrm{OR}^{\mathrm{a}}$ & & & & & & & & & & & & \\
\hline & $O R^{b}$ & & -- & & -- & -- & -- & -- & -- & -- & -- & -- & -- \\
\hline \multirow{3}{*}{$\begin{array}{l}\text { Lophopanopeus } \\
\text { bellus }\end{array}$} & $\mathrm{OR}^{a}$ & & & & & & & & & & & & \\
\hline & $O R^{b}$ & & -- & & -- & -- & -- & -- & -- & -- & -- & -- & -- \\
\hline & $\mathrm{CA}$ & & & & & & -- & -- & -- & -- & -- & -- & -- \\
\hline
\end{tabular}

\begin{tabular}{|c|}
\hline $\begin{array}{c}\text { Maximum observed } \\
\text { density }\left(100 \mathrm{~m}^{3}\right)\end{array}$ \\
\hline$>10000$ \\
$1000-10000$ \\
$100-1000$ \\
$10-100$ \\
$0.1-10$ \\
0 \\
$--\quad$ no data \\
\hline
\end{tabular}

Fig. 9. Cross-shelf distributions and the maximum density (no. larvae $100 \mathrm{~m}^{-3}$ ) of 14 taxa of crustaceans collected off Newport, Oregon, from 1969 to $1971{\left(\mathrm{OR}^{\mathrm{a}}\right.}_{\text {; }}$ Lough 1974) and 1998 to 2002, 2009 and $2010\left(\mathrm{OR}^{\mathrm{b}}\right.$; present study) and Bodega Bay, California, in 2005 and 2006 (CA, Morgan et al. 2009a) ther offshore $(<9 \mathrm{~km})$ during our long-term study. Hemigrapsus spp. larvae also developed nearshore during the earlier study in this region (Lough 1974), although they occurred farther offshore during our study $(9 \mathrm{~km})$ and off northern California $(<13 \mathrm{~km})$. In contrast, Pugettia spp. larvae occurred within $9 \mathrm{~km}$ of the coast during this study but occurred farther offshore during the previous study in this area (Lough 1974) and off northern California (Morgan et al. 2009a). Cancer magister, C. oregonensis and Lophopanopeus bellus migrated across the shelf in central Oregon as well as off northern California. Despite differences in the strength and persistence of upwelling, these interspecific cross-shelf distributions were generally consistent across the CCS and through time, with larvae occasionally occurring somewhat farther offshore during our study (having sampled more years). Thus, it appears that larvae are undertaking reliable cross-shelf migrations rather than being passively advected across the shelf in upwelling regions.

Depth regulation by larvae maintains their crossshelf distribution in highly advective upwelling regimes. Although we do not have information on the vertical distribution of larvae from this study, the horizontal distributions of larvae in the CCS have been shown to be regulated by depth preferences and ontogenetic and diel vertical migrations (Morgan et al. 2009a, 2012, Shanks \& Shearman 2009, Morgan \& Fisher 2010, Miller \& Morgan 2013a,b) and by diel vertical migrations in other upwelling regimes (Poulin et al. 2002, Marta-Almeida et al. 2006). Larvae remain nearshore by either staying beneath the offshore-moving surface Ekman layer or by rising to the surface only at night after prevailing winds sub- 
side. In contrast, larvae that migrate farther offshore spend more time in the Ekman layer. The same suite of behaviors also regulates interspecific and ontogenetic differences in both cross-shelf migrations and alongshore transport by copepods and invertebrate larvae across upwelling regions (Peterson et al. 1979, 1998, Lamb \& Peterson 2005, Papastephanou et al. 2006, Drake et al. 2011, 2013, Domingues et al. 2012).

Physical circulation of the inner shelf facilitates nearshore larval retention and reduced alongshore transport. Ekman transport from our study region is limited to the upper $5 \mathrm{~m}$ of the water column within $10 \mathrm{~km}$ of the coast and is greatly reduced 1 to $2 \mathrm{~km}$ from shore by frictional forces at the land-sea interface (Peterson et al. 1979, Kirincich et al. 2005). Nearshore velocity profiles at 5 sites in California revealed a logarithmic cross-shore gradient in alongshore currents that can reduce larval dispersal distances and increase self-recruitment (Nickols et al. 2012, 2013). The interaction of the coastal boundary layer and larval behavior typically have not been incorporated into physical circulation and connectivity models, but the recent inclusion of behavior alone greatly reduced model predictions of cross-shore and alongshore transport (Roughan et al. 2005, Marta-Almeida et al. 2006, Petersen et al. 2010, Drake et al. 2011, 2013, Lindsey \& Batchelder 2011, Domingues et al. 2012, Robins et al. 2013).

\section{Larval abundance between upwelling regions}

Larval abundances throughout development were remarkably similar across upwelling regions in our study - the first direct comparison of larval assemblages. Only 1 larval stage of 1 species differed for the 8 taxa studied off California and Oregon even though differences in the strength and persistence of upwelling affect productivity and advection across these regions. Strong upwelling may increase larval losses from offshore advection (Roughgarden et al. 1988), reducing recruitment to nearshore communities (Connolly et al. 2001, Menge et al. 2003, 2004, Lagos et al. 2008) and reducing reproductive output (Morgan 2001). We now know that differences in advection do not necessarily affect cross-shelf distributions of larvae (Morgan et al. 2009a,b, 2012, Shanks \& Shearman 2009, Morgan \& Fisher 2010), nor does larval abundance appear to differ (based on a 1 year comparison) among multiple species in Oregon and California. If the similarity of larval abundance across upwelling regions is confirmed in subsequent studies, then reproductive output and planktonic larval mortality cannot explain the latitudinal gradient in recruitment and adult densities, making it more likely that differences in nearshore processes (e.g. surfzone hydrodynamics) determine the ability of larvae to reach the shore (Rilov et al. 2008, Dudas et al. 2009, Shanks et al. 2010).

In conclusion, larvae of most taxa developed within $9 \mathrm{~km}$ of the coast, while the remaining few taxa migrated farther across the shelf. These interspecific differences in cross-shelf migration were reliably maintained across changing oceanographic conditions for many years in Oregon as well as across different regions of the CCS. Larval behaviors and reduced Ekman transport in the coastal boundary layer have previously been shown to maintain these larval migration patterns. There was little difference in abundance throughout development for the assemblage of benthic crustacean larvae across upwelling regions, further indicating that processes within the nearshore coastal zone may be responsible for the latitudinal differences in recruits and adults on rocky shore communities. Larval abundances across upwelling regions should be determined for diverse taxa in more years coupled with studies of nearshore hydrodynamics to further test this hypothesis.

Acknowledgements. We thank L. Feinberg, T. Shaw, J. Menkel, J. Peterson, J. Keister, S. Miller, M. Robart, M. Sheridan, M. Loosekoot, W. White, and D. Dann for assistance in the field. We thank an anonymous reviewer for helpful suggestions with data analysis. This research was funded by the Global Ocean Ecosystems Dynamics program (GLOBEC), NOAA-National Marine Fisheries Service Stock Assessment Improvement Plan, Comparative Analysis of Marine Ecosystem Organization (CAMEO; NA09NMF 4720182), NOAA-Fisheries and the Environment (FATE), Oregon Sea Grant (R/HBT-15), California Sea Grant (R/FISH-2018) and the National Science Foundation (Biological Oceanography awards OCE-0326110 and OCE092735). This is a contribution of GLOBEC, the Hatfield Marine Science Center and the Bodega Marine Laboratory.

\section{LITERATURE CITED}

Austin JA, Barth JA (2002) Variation in the position of the upwelling front on the Oregon shelf. J Geophys Res 107: 3180, doi:10.1029/2001JC000858

> Bograd SJ, Schroeder I, Sarkar N, Qiu X, Sydeman WJ, Schwing FB (2009) Phenology of coastal upwelling in the California Current. Geophys Res Lett 36:L01602, doi:10.1029/2008GL035933

Broitman BR, Blanchette CA, Menge BA, Lubchenco J and others (2008) Spatial and temporal patterns of invertebrate recruitment along the west coast of the United States. Ecol Monogr 78:403-421

Caley MJ, Carr MH, Hixon MA, Hughes TP, Jones GP, Menge BA (1996) Recruitment and the local dynamics of 
open marine populations. Annu Rev Ecol Syst 27: 477-500

Clark KR, Warwick RM (2001) Change in marine communities: an approach to statistical analysis and interpretation, 2nd edn. Natural Environment Research Council, Plymouth Marine Laboratory, Plymouth

Connolly SR, Roughgarden J (1998) A latitudinal gradient in northeast Pacific intertidal community structure: evidence for an oceanographically based synthesis of marine community theory. Am Nat 151:311-326

Connolly SR, Menge BA, Roughgarden J (2001) A latitudinal gradient in recruitment of intertidal invertebrates in the northeast Pacific Ocean. Ecology 82:1799-1813

> Domingues CP, Nolasco R, Dubert J, Queiroga H (2012) Model-derived dispersal pathways from multiple source populations explain variability of invertebrate larval supply. PLoS ONE 7:e35794

Dorman CE, Dever EP, Largier JL (2006) Buoy measured wind, wind stress and curl of the wind stress over the shelf off Bodega Bay, California. Deep-Sea Res 53:2850-2864

Drake PT, Edwards CA, Barth JA (2011) Dispersion and connectivity estimates along the US west coast from a realistic numerical model. J Mar Res 69:1-37

Drake PT, Edwards CA, Morgan SG, Dever WP (2013) Influence of larval behavior on transport and population connectivity in a realistic simulation of the California Current System. J Mar Res 71:317-350

$>$ Dudas SE, Rilov G, Tyburczy J, Menge BA (2009) Linking larval abundance, onshore supply and settlement using instantaneous versus integrated methods. Mar Ecol Prog Ser 387:81-95

Gaines S, Roughgarden J (1985) Larval settlement rate: a leading determinant of structure in an ecological community of the marine intertidal zone. Proc Natl Acad Sci USA 82:3707-3711

Gonor JJ, Gonor SL (1973) Variations in appendage setal counts in zoea larvae of four porcellanid crabs (Decapoda Anomura) from Oregon. Crustaceana 25:245-252

Huyer A (1983) Coastal upwelling in the California current system. Prog Oceanogr 12:259-284

Jensen GC (1995) Pacific coast crabs and shrimps. Sea Challengers, Monterey, CA

> Kaplan DM, Largier JL, Botsford LW (2005) HF radar observations of surface circulation off Bodega Bay (northern California, USA). J Geophys Res 110:C10020, doi: 10.1029/2005JC002959

Kirincich AR, Barth JA, Grantham BA, Menge BA, Lubchenco J (2005) Wind-driven inner-shelf circulation off central Oregon during summer. J Geophys Res 110: C10S03, doi:10.1029/2004JC002611

> Lamb J, Peterson W (2005) Ecological zonation of zooplankton in the COAST study region off central Oregon in June and August 2001 with consideration of retention mechanisms. J Geophys Res 110:C10S15, doi:10.1029/ 2004JC002520

> Largier JL, Magnell BA, Winant CD (1993) Subtidal circulation over the northern Californian shelf. J Geophys Res 98:18147-18179

> Lentz SJ, Chapman DC (1989) Seasonal differences in the current and temperature variability over the northern California Shelf during the Coastal Ocean Dynamics Experiment. J Geophys Res 94:12571-12592

Lindsey BJ, Batchelder HP (2011) Cross-shelf distribution of Euphausia pacifica in the Oregon coastal upwelling zone: field evaluation of a differential transport hypothe- sis. J Plankton Res 33:1666-1678

Lough R (1974) Dynamics of crab larvae (Anomura, Brachyura) off the Central Oregon Coast, 1969-1971. PhD dissertation, Oregon State University, Corvallis, OR

> Marshall DJ, Morgan SG (2011) Ecological and evolutionary consequences of linked life-history stages in the sea. Curr Biol 21:R718-R725

Marta-Almeida M, Dubert J, Peliz A, Queiroga H (2006) Influence of vertical migration pattern on retention of crab larvae in a seasonal upwelling system. Mar Ecol Prog Ser 307:1-19

Menge BA, Lubchenco J, Bracken MES, Chan F and others (2003) Coastal oceanography sets the pace of rocky intertidal community dynamics. Proc Natl Acad Sci USA 100: 12229-12234

Menge BA, Blanchette C, Raimondi P, Freidenburg T and others (2004) Species interaction strength: testing model predictions along an upwelling gradient. Ecol Monogr 74:663-684

> Miller SH, Morgan SG (2013a) Interspecific differences in depth preference: regulation of larval transport in an upwelling regime. Mar Ecol Prog Ser 476:301-306

> Miller SH, Morgan SG (2013b) Phenotypic plasticity in larval vertical migrations in estuarine and coastal populations. J Exp Mar Biol Ecol 449:45-50

Morgan SG (2001) The larval ecology of marine communities. In: Bertness MD, Gaines SD, Hay ME (eds) Marine community ecology. Sinauer Associates, Sunderland, MA, p 159-181

> Morgan SG, Fisher JL (2010) Larval behavior regulates nearshore retention and offshore migration in an upwelling shadow and along the open coast. Mar Ecol Prog Ser 404:109-126

- Morgan SG, Fisher JL, Miller SH, McAfee ST, Largier JL (2009a) Nearshore retention and cross-shelf migration of larvae in a region of strong upwelling and recruitment limitation. Ecology 90:3489-3502

> Morgan SG, Fisher JL, Mace AJ, Akins L, Slaughter AM, Bollens SM (2009b) Cross-shelf distributions and recruitment of crab postlarvae in a region of strong upwelling. Mar Ecol Prog Ser 380:173-185

> Morgan SG, Fisher JL, McAfee ST, Largier JL, Halle CM (2012) Limited recruitment during relaxation events: larval advection and behavior in an upwelling system. Limnol Oceanogr 57:457-470

> Nickols KJ, Gaylord B, Largier JL (2012) The coastal boundary layer: predictable current structure decreases alongshore transport and alters scales of dispersal. Mar Ecol Prog Ser 464:17-35

> Nickols KJ, Miller SH, Gaylord B, Morgan SG, Largier JL (2013) Spatial differences in larval abundance within the coastal boundary layer impact supply to shoreline habitats. Mar Ecol Prog Ser 494:191-203

Papastephanou KM, Bollens SM, Slaughter AM (2006) Cross-shelf distribution of copepods and the role of event-scale winds in a northern California upwelling zone. Deep-Sea Res II 53:3078-3093

Pepin P, Shears TH (1996) Variability and capture efficiency of bongo and Tucker trawl samplers in the collection of ichthyoplankton and other macrozooplankton. Can J Fish Aquat Sci 54:765-773

> Petersen CH, Drake PT, Edwards CA, Ralston S (2010) A numerical study of inferred rockfish (Sebastes spp.) larval dispersal along the central California coast. Fish Oceanogr 19:21-41 
Peterson WT (1998) Life cycle strategies of copepods in coastal upwelling zones. J Mar Syst 15:313-326

> Peterson WT, Miller CB, Hutchinson A (1979) Zonation and maintenance of copepod populations in the Oregon upwelling zone. Deep-Sea Res Part A 26:467-494

Peterson WT, Keister JA, Feinberg LR (2002) The effects of the 1997-99 El Niño/La Niña event on hydrography and zooplankton off the central Oregon coast. Prog Oceanogr 54:381-398

Pfaff MC, Branch GM, Wieters EA, Branch RA, Broitman BR (2011) Upwelling intensity and wave exposure determine recruitment of intertidal mussels and barnacles in the southern Benguela upwelling region. Mar Ecol Prog Ser 425:141-152

Poulin E, Palma AT, Leiva G, Narvaez D, Pacheco R, Navarrete SA, Castilla JC (2002) Avoiding offshore transport of competent larvae during upwelling events: the case of the gastropod Concholepas concolepas in Central Chile. Limnol Oceanogr 47:1248-1255

> Queiroga H, Blanton J (2005) Interactions between behavior and physical forcing in the control of horizontal transport of decapod crustacean larvae. Adv Mar Biol 47:107-214

Queiroga H, Cruz HT, dos Santos A, Dubert J and others (2007) Oceanographic and behavioural processes affecting invertebrate larval dispersal and supply in the western Iberia upwelling ecosystem. Prog Oceanogr 74: 174-191

Rilov G, Dudas SE, Menge BA, Grantham BA, Lubchenco J, Schiel DR (2008) The surf zone: a semipermeable barrier to onshore recruitment of invertebrate larvae? J Exp Mar Biol Ecol 361:59-74

Robins PE, Neill SP, Gime'nez L, Jenkins SR, Malham SK (2013) Physical and biological controls on larval dispersal and connectivity in a highly energetic shelf sea. Limnol Oceanogr 58:505-524

Roughan M, Mace AJ, Largier JL, Morgan SG, Fisher JL, Carter ML (2005) Subsurface recirculation and larval retention in the lee of a small headland: a variation on the upwelling shadow theme. J Geophys Res 110: C10027, doi:10.1029/2005JC002898

Roughan M, Garfield N, Largier J, Dever E, Dorman C,

Editorial responsibility: Karen Miller,

Hobart, Tasmania, Australia
Peterson D, Dorman J (2006) Transport and retention in an upwelling region: the role of across-shelf structure. Deep-Sea Res II 53:2931-2955

Roughgarden J, Gaines S, Possingham H (1988) Recruitment dynamics in complex life cycles. Science 241: 1460-1466

Schmitt WL (1921) The marine decapod Crustacea of California. University of California Publications in Zoology, Vol 23. University of California Press, Berkeley, CA

Shanks AL, Eckert GL (2005) Population persistence of California Current fishes and benthic crustaceans: a marine drift paradox. Ecol Monogr 75:505-524

Shanks AL, Roegner GC (2007) Recruitment limitation in Dungeness crab populations is driven by variation in atmospheric forcing. Ecology 88:1726-1737

Shanks AL, Shearman RK (2009) Paradigm lost? Cross-shelf distributions of intertidal invertebrate larvae are unaffected by upwelling or downwelling. Mar Ecol Prog Ser 385:189-204

Shanks AL, Morgan SG, MacMahan J, Reniers JHM (2010) Surf zone physical and morphological regime as determinants of temporal and spatial variation in larval recruitment. J Exp Mar Biol Ecol 392:140-150

Strathmann R, Hughes T, Kuris A, Lindeman K, Morgan S, Pandolfi J, Warner R (2002) Evolution of local recruitment and its consequences for marine populations. Bull Mar Sci 70:377-396

Tapia FJ, Pineda J (2007) Stage-specific distribution of barnacle larvae in nearshore waters: potential for limited dispersal and high mortality rates. Mar Ecol Prog Ser 342:177-190

Underwood AJ, Keough MJ (2001) Supply-side ecology: the nature and consequences of variations in recruitment of intertidal organisms. In: Bertness MD, Gaines SD, Hay ME (eds) Marine community ecology. Sinauer Associates, Sunderland, MA, p 183-200

Winant CD, Beardsley RC, Davis RW (1987) Moored wind, temperature and current observations made during Coastal Ocean Dynamics Experiments 1 and 2 over the northern Californian continental shelf and upper slope. J Geophys Res 92:1569-1604

Submitted: May 2, 2013; Accepted: January 14, 2014

Proofs received from author(s): March 28, 2014 